\title{
LABIRINTO DO AUTOR, QUEIXANDO-SE DO MUNDO: CORRE SEM VELA E SEM LEME
}

Marcia Arruda Franco

Universidade de São Paulo

Para Jorge Fernandes da Silveira

RESUMO

O presente artigo pretende estudar o labirinto de Luís de Camões, a fim de pensar uma história das formas poéticas, desde a antiguidade à contemporaneidade.

Palavras-chave: Camões, Labirinto, História das formas poéticas.

ABSTRACT

The following paper means to study the labyrinth of Camoens in order to think a history of poetic forms, from ancient times to our days.

Camoens, Labyrinth, History of poetic forms.

Como a sextina, "Foge-me pouco a pouco a curta vida", a Glosa ao mote de Dona Francisca de Aragão, "Mas porém a que cuidados", o "ABC em Motes", as trovas "Sois ũa dama", e outras tantas, a composição que vamos examinar, "Labirinto do autor, queixando-se do mundo" (Vide Apêndice), ${ }^{1}$ organiza-se por uma construção da linguagem poética que de alguma forma não exatamente ingênua aproxima, em termos formais, a poesia de Luís de Camões da prática poética contemporânea. Isto é, daquela que, tal qual João Cabral de Melo Neto, entende o poema como um ato de linguagem, uma composição de palavras, fruto duma elaboração técnica e filosófica, que apesar de distinta do ponto de vista histórico, do ponto de vista de uma história das formas e dos gêneros poéticos, guarda algo de semelhante com a composição por engenho e arte, característica da poesia aguda, na passagem do século XVI para o XVII. Este aspecto da poesia figurativa, visual e labiríntica está minimamente presente na grafia de qualquer escrita, como imagem visual e sonora, a ser ativada ou posta em uso por um leitor ativo, capaz de construir sentido com o objeto de palavras.

O labirinto, como forma poética, contempla o lúdico não só ao quebrar a linearidade de leitura do poema, por meio da explosão sintagmática para a elaboração de conceitos, como é o caso do labirinto de versos de Camões, mas também contempla a ludicidade na própria construção visual da forma. Na poesia labiríntica figurativa, a ordem semântico-sintática tem de ser recuperada através do jogo de decifrar o enigma proposto pela disposição visual dos grafemas, organizada como desenho de um objeto: o ovo, a flauta, o altar, o cubo, o leque, a chuva, o rotor. Nos poemas figurativos contemporâneos, como noutros poemas visuais dos séculos XVI, XVII e XVIII, trata-se

\footnotetext{
${ }^{1}$ Todos estes poemas encontram-se na edição de Maria de Lurdes Saraiva da Lírica completa, Volume I. Ver lista bibliográfica.
} 
duma evocação de prática poética antiga, do conjunto de poemas figurativos divulgados na Antologia Palatina: de Simias de Rodes, três poemas em formato de machado, de asas e de ovo; de Teócrito, a Flauta de Pã, e, de Dosiadas e de Vestinus, os dois Altares (menor e maior), ${ }^{2}$ todos a propor o jogo da reorganização da seqüência ou renumeração de versos, a indicarem ao leitor outra direção de leitura, feita justamente pela quebra na ordem de leitura que a escrita ocidental impõe ao texto. Não se trata mais de ler o poema apenas da esquerda para a direita e de cima para baixo. Para decifrar o labirinto de versos em forma semi-alada, do quinhentista português Pero de Andrade Caminha, por exemplo, é preciso ler o primeiro e o ultimo verso, o segundo e o penúltimo, o terceiro e o antepenúltimo até o meio do poema (Vide Apêndice). Esta direção de leitura de fora para o centro, ou enovelada, é que se imita do labirinto antigo.

"As Asas de Eros" serviram de modelo a este contemporâneo de Luiz de Camões, Pero de Andrade Caminha, por exemplo, no epigrama dirigido "Ao Padre Bartolomeu Cancela da Companhia de Jesus". Do poema votivo de Simias de Rodes, o epigrama de Andrade Caminha retoma, a par do aspecto visual apenas semi-alado, o ser uma espécie de prece ou reza, feita não ao deus mitológico, mas a um religioso da Igreja Católica. Nesse poema visual, o deslize do sentido de asas do campo semântico de Eros para o da doutrinação católico-cristã nota-se desde o primeiro verso: “Oh com que fermosas asas de doutrina" (Anastácio, 1998, vol. 2, p. 796, n536). O mesmo tom de prece por uma regeneração religiosa e moral do Império lusitano perpassa o labirinto em redondilhas, "Virgem de mil graças cheia", de Fernão Álvares do Oriente. Este labirinto, ao divino, está esculpido numa coluna de mármore do poço do labirinto onde estão as personagens desta obra híbrida de prosa e poesia. Cada personagem-leitor reinventa a ordem de entendimento deste labirinto-poético, impresso num encarte dobrado, explicitando o caráter de jogo desta forma e de coisa do poema. Mas há dois labirintos na Lusitânia Transformada. O outro labirinto é composto por Florampo e o primeiro verso é "Eterno movedor em quem se encerra" (Vide Apêndice).

De certo, no século XVI, os poetas deram outro sentido aos poemas votivos da Grecia antiga, inscrevendo-os como formas legítimas e funcionais da poesia de seu tempo, no plano religioso ou profano. Tal é facilmente verificável ainda em dois epigramas visuais do mesmo Caminha (Anastácio, 1998, pp.244-5, n 219 e $\mathrm{n}^{\circ} 220$ ), ambos em louvor de Filis, em forma de flauta de Pã, como o poema figurativo de

\footnotetext{
${ }^{2}$ Uma publicação destes poemas encontra-se no texto de Legrand indicado na lista bibliográfica.
} 
Teócrito: "Em toda sorte de versos cantada" e "Nunca vi" (Vide Apêndice). Ao circular com outras funções, à forma antiga do labirinto se confere novo vigor quinhentista.

De uma maneira geral, para os tratadistas, o que caracteriza a forma do labirinto é o aspecto lúdico de suspensão da ordem linear da leitura, ou seja, a possibilidade de arranjos diversificados na seqüência da leitura é o que define como forma poética o labirinto de versos independentemente da mímese de uma figura ou não. Aí se enquadra o labirinto de Luís de Camões, Corre sem vela e sem leme. É nas múltiplas possibilidades de entradas e arranjos de leitura que está o seu caráter lúdico, a exigir a construção de sentido por parte de um leitor ativo.

Na Arte Poética Espanhola, de Rengifo, de 1606, o labirinto de palavras ou de letras difere do labirinto de versos inteiros, pois os primeiros são constelações de palavras ou letras, cuja chave sintática tem de ser construída a partir da visualidade da forma, enquanto o labirinto de versos abriga a multiplicidade de direções de leitura. Segundo o mesmo tratadista, o que caracteriza a forma do labirinto de versos, palavras ou letras é o aspecto lúdico de suspensão da ordem linear da leitura. As diversas possibilidades de ordenação dos versos e montagem das estrofes assinalam o seu caráter de jogo verbal, a exigir a construção de sentido por parte de um leitor que o descodifique num lance, jogada ou reordenação de leitura. Rengifo (1606/2007, p.95) expõe a diversidade mecânica dos labirintos de versos inteiros, alguns lidos em letra de mão: uns que são "leydos al derecho, o al reves, saltados o cruzados, o de otras maneras, siempre hazen copla", como Corre sem vela e sem leme; e outros, dos quais "no solo se leen los versos de muchas maneras, pero leydos de una hazen un sentido, y leydos de otra hazen el contrario: y componense de coplas de Arte mayor, y de Redondilhas menores". É visível a confecção das trovas Sois uma dama (Vide Apêndice), com dois entendimentos contrários, o elogio e o vitupério da dama, nos moldes das cantigas de amor e de mal-dizer, conforme se leia na horizontal, em versos de arte maior, ou na vertical, em redondilha menor, segundo regras semelhantes às de Rengifo, de modo "que lo que se va afirmando en la copla menor, se niegue en la mayor, o al contrario". Tais estâncias labirinticas camonianas, releitura palaciana quinhentista, e seiscentista, do código trovadoresco medieval, foram pela primeira vez impressas apenas na edição de 1668, com a rubrica: "Estâncias na medida antiga que têm duas contrariedades, louvando e deslouvando a dama".

No âmbito iberoamericano, as diversas maneiras de labirinto foram escritas em língua vulgar como o bastante citado soneto em labirinto de Gregório de Matos e 
Guerra, Ao mesmo desembargador Belchior de Cunha Brochado, mas também em latim, basta citar o celebérrimo labirinto cúbico de Anastacio Aires de Peñafiel. Ana Haterly, por meio de edições como A experiência do prodígio, de 1983, e A casa das Musas, de 1995, ou na direção editorial da revista Claro Escuro, publicou inúmeros labirintos, cuja prática se estende até o século XVIII, como é o caso do Epithalâmio, de Jerónimo Tavares Mascarenhas de Távora, de 1738.

O labirinto, praticado por uma série de autores pré-românticos, ressurgiu como um recurso criativo legítimo e ativo, por meio dos caligramas, ao longo do século $\mathrm{XX}$, de Apollinaire e Huidobro a Augusto de Campos. Há semelhanças entre algumas soluções gráfico-visuais do labirinto de Gregório de Matos e Guerra e a poesia concretista paulista, mas a diferença histórica entre as duas formas de poesia lúdica traz diferenças irredutíveis de função e concepção, em cada momento ou lugar de revitalização da forma visual antiga. As formas e os gêneros poéticos, ao serem cultivados em novos tempos e espaços, carregam em si a sua historicidade, ou a referência ao contexto cultural em que foram criados, todavia o fazem sem rigidez e sim de forma flexível, o que permite a sua retomada legítima, como processo criativo sempre renovado ou renovável de determinada forma ou gênero, em tempos e lugares posteriores ao da sua composição, isto é, do ponto de vista histórico da sua recepção criativa ou releitura poética. Trata-se no século XX de reinventar uma forma poética do acervo da poesia ocidental mais ou menos como os renascentistas elegiam modelos antigos como objeto de uma emulação. Determinadas formas (o soneto, a sextina, o labirinto, a canção, a terça e oitava rimas, as trovinhas) e gêneros discursivos (lírico, bucólico, dramático, satírico, epistolar, elegíaco, encomiástico) adquiriram uma transhistoricidade, por meio do fenômeno da modelização e da variação, que os permite passar por um processo de revigoramento, a partir de re-elaborações, sempre históricas, que dirigem o novo ato de linguagem ou de composição gráfica para o próprio tempo e espaço da nova enunciação. O labirinto quinhentista ou seiscentista, citando, em diferença, os poemas votivos gregos, ressurge também na poesia contemporânea, quando se apodera do lúdico e mobiliza o seu receptor com o jogo verbal da poesia. A poesia lúdica, labiríntica e visual, como recurso de composição poética, viaja na história, e é posta novamente em uso pelos poetas de agora, nos alvores do século XXI. Bastava citar a caixa de poemas, "objeto", ou o "rotor", de Ronald Polito, entre os brasileiros. 
Evidentemente a revisitação do passado pelo presente não pretende enfocar o momento histórico de sua produção e sim o da sua releitura poética, de outro ponto de vista da história, o da recepção da obra, pela crítica e pelos poetas, cuja mentalidade se apresenta na releitura homologada pela instituição literária ou juízo crítico então em voga. A crítica literária e a revisitação das formas e gêneros do passado pelos poetas passam a ser preciosas lupas para a investigação histórica do passado, pois da história da recepção crítica ou criativa de uma obra escoa e escorre, por um esquema complexo de valores e desejos, como se pensava e se julgava, nos diversos momentos históricos em questão. Assim o uso da poesia visual ou labiríntica em momentos diferentes da história das formas e dos gêneros pode esclarecer a respeito da especificidade histórica de cada época e também criar um elo de comparação entre tempos tão distantes, determinando as divergências e convergências no uso, no cultivo e na função da poesia visual e labiríntica.

Por meio do trabalho jornalístico de Mário Faustino, de início, e pelo de tradução dos irmãos Campos, que reescreveram na língua portuguesa uma série de poemas de Arnault Daniel, John Donne, Homero, Símias de Rodes e de tantos outros, os leitores de poesia no Brasil abriram os olhos e puderam perceber em poetas quinhentistas e seiscentistas da língua portuguesa, como Camões, Sá de Miranda, Gil Vicente, Gregório de Matos, algumas características poéticas ainda atuantes no presente, isto é, não apenas representativas de seu tempo, mas também altamente interativas com o século XX e XXI. É lícito conceituar o poema como um artefato de linguagem, trabalhada, como elucida Pound para os novecentistas, ao nível da imagem, do som e do conceito, isto é, uma coisa de palavras, ou um objeto retórico, cujo sentido se dirige ao seu público ideal, ou àquele que compartilhe de um mesmo horizonte de expectativas do poético. Neste sentido, a poesia visual e labiríntica encontra um meio ótimo na informatização das letras. Tal convergência entre obra, tecnologia e público não se restringe ao primeiro horizonte coevo de recepção. $O$ discurso literário e em verdade qualquer texto pode descolar-se do seu contexto para a construção de novos sentidos, objeto ao longo do tempo, como dinâmica do ato da leitura, das variadas releituras. Tais re-significações da obra sem dúvida são anacrônicas do ponto de vista do tempo em que esta foi escrita ou composta, mas são bem contemporâneas do próprio contexto em que a obra é relida novamente, indicando os limites históricos das interpretações, ao explicitar a mentalidade geral da época da releitura. Do ponto de vista do presente, que valoriza o poético como coisa de palavras, é precisamente como 
exemplo do virtuosismo retórico de Luiz de Camões que ainda interessa reler esta peça tão engenhosa e aguda do século XVI português.

Paul Zumthor nos explica a trans-historicidade aludida do poema visual, ao entendê-lo como um modelo geral de atitudes de escrita, que ressurge em determinados momentos, com as suas marcadas variações funcionais e históricas. Toda escrita na medida em que é grafada faz-se imagem, o que a supõe como um desenho, um risco sobre o papel, um traço gráfico que significa, no entanto, não exatamente pela forma (como é o caso do labirinto de palavras ou letras e do poema figurativo), mas pelo que representa como som e sentido ao seu possível receptor. Os labirintos de palavras e de letras diferem do labirinto de versos justamente aí, pois os primeiros são uma constelação de palavras ou letras cuja chave sintática ou lexical tem de ser construída apenas a partir da visualidade da forma, enquanto o labirinto de versos abriga a multiplicidade de direções de leitura, a partir da potenciação de relações visuais, sonoras, sintáticas e semânticas, no seio da linguagem verbal e escrita, sendo, por assim dizer, pura retórica. É por isso que o labirinto de versos não é vazio de sentido como facilmente acontece com os labirintos de palavras ou letras, os quais, uma vez encontrada a chave de leitura, se revelam banalíssimos, do ponto de vista da reflexão poética empreendida, inscrevendo-se como um meio rebuscado ou sofisticado de comunicação para as mais triviais formas de convívio social letrado, profano e religioso. Há uma espécie de quebra do equilíbrio entre som, sentido e imagem, de modo que esta última evidencia o ar decorativo e de pouco sentido do labirinto de palavras ou letras.

O labirinto de versos cultivado por Camões, como emulação do modelo grego antigo, e também da "Ode ad Republicam", de Horácio, ao contrário, sugere uma reflexão profundamente cristã, característica do século XVI português, ao se inscrever na fronteira entre o uso religioso e satírico da palavra poética: através de uma maldição, a lenda negra do império lusíada é alvo de uma crítica ético-moral e religiosa.

No labirinto do autor, ao contrário do que acontece em Os Lusíadas, as imagens da navegação sugerem o lado negativo da aventura marítima, ao serem ressaltados, não os seus traços épicos, mas os riscos nela implicados. O sentido geral recuperado em todas as direções de leitura é o desgoverno do leme por parte dos nautas portugueses. A reiterada maldição do labirinto se profere de acordo com a visão católico-cristã de mundo: na hora da morte, tendo exercido um mau ou falso cristianismo nas lides do Oriente, o nauta lusitano será punido com o inferno, náufrago eterno da cobiça e da ambição. 
A partir das imagens náuticas, coadas da ode I, 14 de Horácio, onde representam uma crítica ao desregramento da sociedade romana, Camões retoma a queixa contra o mundo mau, ou em desconcerto, dos navegadores lusíadas. Horácio lhe fornece as imagens para a nave desgovernada, no mar em fúria, e o seu uso como sátira social, na tradução editada por Bento Prado de Almeida Ferraz: “Ó nau, de novo, ao largo mar te levam / as ondas! Oh! Que fazes? Tem-te às praias / com decisão. Não vês teu flanco nu / de remos e teu mastro já quebrado pelo Ártico veloz? Não vês que as vergas / gemem e as quilhas, sem amarras já, / quase não podem suportar o mar / em fúria? E velas íntegras não tens?” (Ferraz, 2003, p. 41).

A nau do império lusíada "corre sem vela e sem leme". O tema do desconcerto do mundo em revolta e confusão, pelo avesso, como tempestade marítima que tudo revolve e subverte encontra-se no Labirinto do autor queixando-se do mundo. Nesta peça lúdica da lírica camoniana, a sintaxe dos versos e a disposição estrófica são construídas como peças soltas a serem remontadas em múltiplas direções de leitura, de cima para baixo, de baixo para cima, pelas estrofes ímpares, pelas pares, emparelhandose versos de mesma posição, re-agrupados em quintilhas ou décimas etc. Na estrutura do labirinto não só a ordem linear do texto é subvertida, mas o corpo fonético, diacrítico e morfológico do léxico sofre uma alteração significante, a fim de se adaptar a determinada direção de leitura. No $9^{\circ}$ verso, por exemplo, o "a" "é nuns casos lido como artigo definido" (Saraiva, 1980, vol.1, p.263) e noutros como crase (à); na ordem normal, de cima para baixo, é artigo: "vendo quanto mal fizeram / a cobiça e ambição"; de baixo para cima, é crase: "Disfarçados se acolheram / à cobiça e ambição". Com a repetição alternada de dois versos (v.18=v.30 e v.20=v.28): "posto que se detiveram" e "sempre castigo tiveram", a significação geral de advertência não é afetada, permanecendo a única saída do labirinto o arrependimento e a vida virtuosa. Por meio da figura de repetição, a mensagem cristã, movendo o crente ao arrependimento, inspirando-lhe o temor, e ameaçando o pecador com a punição, mantém-se, em qualquer direção assumida de leitura. Por exemplo, na normal, de cima para baixo, a última quintilha adverte a nobreza: "Os que nunca trabalharam / tendo o que lhe não convém,/ se ao inocente exploraram, / perderão o eterno bem / se do mal não se apartaram". Pela leitura emparelhada dos versos finais de cinco décimas, de cima para baixo, os que exploraram os justos e os inocentes são castigados: “disfarçados se acolheram / os que o justo profanaram / sempre castigos tiveram / posto que se detiveram / se do mal não se apartaram" (Camões, 1980, vol.1, p.263). Entretanto, se construirmos uma décima, a 
partir das dez quintilhas, escolhendo de propósito apenas o $4^{\circ}$ verso, para além do uso dos versos repetidos, acima citados, que ocupam nas quintilhas as posições de terceiro e quinto versos, ainda explicita-se tal mensagem: "O que perigo não teme / a cobiça e ambição / vejo perigos correr / de demônios hábito tem / aquele que quer valer / com esta simulação / se merece, grita e geme / sem nenhuma redenção / sem que lhe valha gemer / perder[á] o eterno bem". O jogo verbal deste labirinto de versos, com as suas múltiplas ordens de entendimento, mobiliza o leitor para a reformulação morfológica do léxico, a fim de ser reconstruída a maldição dos versos contra o pecador.

Na edição de Maria de Lurdes Saraiva, reimpressa desde 1980, e a mais simples de se adquirir ainda hoje, o Labirinto é o poema que precede a conhecida sátira “Disparates da Índia”. Esta descreve o desregramento cristão do Estado da Índia por meio da sátira aos tipos sociais envolvidos no processo da conquista dos portos do Oriente. A mesma crítica está presente no "Labirinto", mas dirigida ao indivíduo que escolhe participar desta engrenagem do comércio ultramarin que fundamenta $o$ Mercantilismo, cuja prática se mostra incompatível com a do bom cristianismo.

Em suma, no século XVI, a forma labiríntica e o poema visual, como na antiguidade, permanecem, cada um à maneira de sua época histórica, circunscritos à prática religiosa, sendo que nesta são votivos ou ficcionam ex-votos, e naquele, e no período literário clássico, em geral, judaico-cristãos, onde aparecem também com a forma profana do louvor amoroso; no século XX, porém, a forma labiríntica, de acordo com o próprio mundo contemporâneo, foi secularizada pelos futuristas, concretistas e poetas de agora, prevalecendo o aspecto lúdico sobre a função religiosa ou líricoamorosa. Ao longo do século XX, a forma poética do labirinto e do poema figurativo pôde ainda se beneficiar tanto da reflexão sobre a língua e sobre a escrita e a leitura, encetada pela linguística, pela teoria da literatura, pela nova filologia e pela história do livro e da leitura, como dos meios digitais e informáticos de transmissão da imagem gráfica. A informatização da circulação poética, sendo um meio ótimo para a divulgação do poema visual, não gera um produto poético-visual necessariamente melhor ou pior, pois compara-se com a tipografia, que, pela gravura em metal, também foi um excelente meio de divulgação da poesia visual no período moderno, ao lado do manuscrito ou desenho. Neste período como agora verifica-se grande desnível na qualidade poética dos labirintos produzidos, pois parece não haver uma relação direta entre função social do poético, tecnologia de produção da poesia visual e qualidade artística, até porque esta última depende de como e de onde se reconstrói a história do discurso poético. O texto 
escrito do labirinto, como desenho ou partitura a ser seguida, é visualizado como coisa, cubo, esquema de escrita, sendo necessário para se aceder às outras ordens de entendimento o contato material com o texto visual. O leitor é instado a construir a sua ordem de leitura. No apêndice a este texto pode-se ler como Fernão Alvares do Oriente propaga o mesmo entendimento da forma labiríntica presente neste trecho de Rengifo abaixo, que regula a poesia labiríntica pela reconstrução da leitura por renovadas ordenações estrofico-rimáticas de sentido:

Labirinto es nombre Griego, y sinifica una casa, o carcel con tantas calles, y bueltas, que entrando uno en el se pierde, y no acierta con la puerta por donde entró; como aquél de Creta, donde los poetas dizen que estuvo el Minotauro, o otros de quem Plínio haze mencion. Llamase tambien labirinto, cierto genero de coplas, o de dicciones, que se puedem leer de muchas maneras: y por qualquiera parte que uno eche, siempre halla passo para la copla, y de pocas coplas haga inumeras, todas con su sentencia, y consonancia perfecta.Hazense estos Labirintos, o de las letras solas metidas entre los versos, o de solos los versos. (Rengifo, 1606/2007, p. 93)

A suspensão da ordem linear de leitura dos versos, dispostos em uma figura ou não, caracteriza o labirinto (de letras, palavras e versos) como forma. Enfim, do ponto de vista de uma história das formas poéticas, o cultivo do labirinto marca algumas constantes que servem justamente para definir a sua especificidade enquanto forma poética, sendo os seus traços estruturantes e metahistóricos, o convite ao jogo da linguagem, a reificação da escrita e o rompimento da linearidade discursiva.

\section{Bibliografia}

ANASTACIO, Vanda, Visões de Glória (uma introdução à poesia de Pêro de Andrade Caminha ), Lisboa: FCG/JNICT, 1998. 2 vols.

CAMÕES, Luís de. Redondilhas e sonetos (a lição das primeiras edições e variantes) com prefácio, notas de Hernani Cidade. Lisboa: Sá da Costa, 1946. Vol. 1.

CAMÕES, Luís de. Lírica completa. Prefácio e notas de Maria de Lurdes Saraiva, Vila da Maia: IN-CM, 1980, Vol.1.

CAMPOS, Augusto. Viva a vaia Poesia (1949 - 1979). São Paulo: Brasiliense, 1986. 
FAUSTINO, Mario. Artesanato de Poesia. Fontes e correntes da poesia ocidental. Organização de Maria Eugênia Boaventura. São Paulo: Companhia das Letras, 2004.

HORACIO, Odes e Epodos, Tradução de FERRAZ, Bento Prado de Almeida. São Paulo: Martins Fontes, 2003.

HATHERLY, Ana. A experiência do prodígio. Bases Teóricas e Antologia de TextosVisuais Portugueses dos séculos XVII e XVIII. Lisboa: IN-CM, 1983.

HATHERLY, Ana. A casa das musas, Lisboa: Editorial Estampa, 1995.

HUIDOBRO, Vicente. Obra Selecta. Selección, prólogo, cronologia, bibliografia y notas de Luis Navarrete Orta. Caracas: Biblioteca Ayacucho, 1989.

La lettre, La figure, Le rebus dans La poétique de La Renaissance. Numéro composé par Gisèle Mathieu-Castellani. Revue des Sciences Humaine. Lille III: 179, 1980-3.

LEGRAND, Ph. E. Poème figures. Notice in Bucoliques Grecs, Tome II, PseudoThéocrite. Paris: Les Belles Lettres, 1967, p.219-235.

MELO NETO, João Cabral. Poesia e composição, A inspiração e o trabalho de arte. Coimbra: Angelus Novus, 2003.

OLIVA NETO, João Ângelo (Tradução do Grego de do latim, Ensaios Introdutórios, Notas e Iconografia), Falo no jardim. Priapéia Grega, Priapéia Latina. São Paulo: Ateliê, 2006.

PAES, José Paulo Poemas da Antologia de Grega ou Palatina. São Paulo: Cia das Letras, 1995.

POLITO, Ronald, objeto, 1991-1997. Edição do autor. Projeto Gráfico: Ronald Polito e Vicente Abreu. Impressão Vicene Abreu. Auxiliar Daniel Mendes. Silk-screen, carimbo e monotipia. Papéis Canson, Color Plus,Chambril premier, papelão e transparência. Capa de cartão duplex. 250 exemplares. Mariana- Ouro Preto: Inverno de 1997.

POLITO, Ronald. "rotor”, in: www.letras.ufrj.br/ciencialit/imagens/rotor.jpg

RENGIFO, Ivan Diaz. Arte Poetica Española, Edição fac-similada. Madrid, Juan de la Cuesta, 1606/2007

SARAIVA, $\mathrm{M}^{\mathrm{o}}$ de Lurdes, ed. Lírica Completa de Luiz de Camões. Lisboa, IN-CM, 1980. 3 Vols.

ZUMTHOR, Paul. D'une poésie littérale, Revues de Sciences Humaine, Tome LI, nº179, p.7-21, Juillet-Septembre 1980.

\section{APÊNDICE}

Luiz de Camões (Transcrição atualizada a partir de SARAIVA) 
Labirinto do autor queixando-se do mundo

Corre sem vela e sem leme

O tempo desordenado

Dum grande vento levado

$\mathrm{O}$ que perigo não teme

É de pouco exprimentado

As rédeas trazem nas mãos

Os que rédeas não tiveram

Vendo quanto mal fizeram

A cobiça e ambição

Disfarçados se acolheram

A nau que se vai perder

Destrui mil esperanças

Vejo o mau que vem a ter

Vejo perigo correr

Quem não cuida que há mudanças

Os que nunca em sela andaram

Na sela postos se vêm

De fazer mal não deixaram

De demônios hábito têm

Os que o justo profanaram

Que poderá vir a ser

O mal nunca refreado

Anda por certo enganado

Aquele que quer valer

Levando o caminho errado

É para os bons confusão

Ver que os maus prevaleceram

Posto que se detiveram

Com esta simulação

Sempre castigos tiveram

Não porque governe o leme

Em mar envolto e turbado

Que tem seu remo mudado

Se merece, grita e geme

Em tempo desordenado

Terem justo galardão

E dor dos que mereceram

Sempre castigos tiveram

Sem nenhuma redenção

Posto que se detiveram 
$\mathrm{Na}$ tormenta se vier

Desespere na bonança

Quem manhas não sabe ter

Sem que lhe valha gemer

Verá falsar a balança

Os que nunca trabalharam

Tendo o que lhe não convém

Se ao inocente enganaram

Perderã o eterno bem

Se do mal não se apartaram

Estâncias na medida antiga, que têm duas contrariedades, louvando e deslouvando uma Dama.

Sois uma dama das feias do mundo de toda a má fama sois cabo profundo A vossa figura não é para ver em vosso poder não há fermosura

Fostes dotada de toda a maldade perfeita beldade de vós é tirada Sois muito acabada de tacha e de glosa pois, quanto a fermosa em vós não há nada
De grão merecer sois bem apartada andais alongada do bem parecer Bem claro mostrais em vós fealdade não há i maldade que não precedais.

De fresco carão vos vejo ausente em vós é presente a má condição De ter perfeição mui alheia estais mui muito alcançais de pouca razão 
Pero de Andrade Caminha (Atualização ortográfica sobre a edição de ANASTÁCIO) I

Em todas as sortes de versos cantada

Deves de ser sempre Fílis com razão.

Deves de todo o engenho ser louvada,

Mas á, quando a louvar-te chegarão?

Nem os versos dirão nada,

Nem engenhos bastarão.

Mas estás tanto acima

De quanto na Terra há:

Que teu nome à rima

Que te cantará

Grand'estima

Lhe dará.

II

Nunca vi

Fermosura

Fílis como a ti

Tem dad'a ventura

E todo tempo assim

Tão firme e tão segura

Em ti o Amor nos mostrou

Tudo o que pode na Terra

Nosso bem, nosso mal em ti juntou,

E nos pôs em teus olhos paz e guerra,

Mas sempr'a paz neles Filis nos negou

Vê bem quanto nist'Amor contra nós erra

III - Ao Padre Bartolomeu Cacela da Companhia de Jesus

Ó com que fermosas asas de doutrina,

E do afervorado e raro espírito teu

Tua eloquencia grão Cacela ensina

As almas para Deus que Deus nos deu

Para na Glória divina

Gosar do descanso seu

Desces á estreta Terra

Que nunca satisfaz

E mostras a guerra

Que o mundo nos faz

E o que o que rra

Morto jaz

Com Amor

Logo voa

Cheia de fervor

Tua alma em quem soa

O Altísssimo Senhor

Nossa Gloria e Coroa

E voando ao sumo bem

Que está na mais alta altura

Com amor nos ensino o que convém

Para alcançar a eterna fermosura

E assim com tais asas quais tua Alma tem

Voar nos ensina à Gloria segura 
Fernão Álvares do Oriente

(Transcrito com a ortografia atualizada a partir de Lusitânia Transformada, 1607, fols. $108-111)$.

Tendo tomados todos um pequeno alento, lançou os olhos Frondoso para o alto duma coluna, que plantada no meio de um pequeno tanque derramava por quatro bocas de serpentes abundante cópia de água, e descobriu por frontespício da coluna, uma tarja de mármore mui bem lavrada, e escrita com letras tão miúdas, que se não podia ler bem dos assentos em que estávamos por onde o mesmo Frondoso, que foi o primeiro, que a todos advertiu daquele segredo sobre a borda do tanque, que abraçava no seio as cristalinas águas, em voz alta começou a ler a escritura, de que a tarja da coluna estava ocupada, pedindo-nos primeiro atenção, que todos de mui boa vontade lhe demos, por escutar a letra, que é a que se contém na página seguinte.

[O labirinto "Virgem de mil graças cheia", impresso num encarte na primeira edição, pode ser visualizado em:

http://www.antoniomiranda.com.br/poesia_visual/img/fernao alvares do oriente1. jpg ]

Depois que Frondoso leu, com satisfação de todos, a letra, que em si tinha o mármore da coluna, estando primeiro um breve espaço mui suspenso, como que alguma coisa estivesse contemplando, e nós com os olhos postos nele esperando o remate, que teria o seu silêncio, voltando para nós mui admirado disse, vejo nessas letras outro labirinto, fabricado por algum alto engenho de que vos confesso, que me não sei sair. Acho, que cada cinco regras destas, respondem umas às outras com tanta consonância, que por onde quer que as tomo, fazem uma tão perfeita, que não só respondem a todas as leis da poesia, mas ao propósito do sentido tão compridamente, que me tem maravilhado o seu estranho artifício. Com tanta pressa nos pusemos todos sobre o paiol, que rodeava o tanque, e mui devagar cada um consigo esteve lendo o letreiro da coluna, e tomando cada um as regras dele por várias partes achava que caiam todas tão a propósito, que não puderam todos deixar de as engrandecer com admiração e gosto de ver os louvores da Senhora engrandecidos por modo tão espantoso. Mas Florampo, que na sutil arte da poesia levava vantagem a muitos da ribeira, e entre todos os seus contemporâneos era nela mui singular, depois de ter um pouco notado a traça daquela compostura, apartando-se para uma parte do intrincado labirinto, que faziam as ervas graciosas, assentado entre elas com o socego do ânimo, e serenidade do rosto, se pôs a tanger no seu rabil um largo espaço, como preparando-nos para o que queria cantar. E tendo-nos com a suavidade do instrumento, que tocava a todos os circunstantes atentos, e satisfeitos, soltou a voz, dando princípio a outro labirinto, que é o que se segue.

Eterno movedor em quem se encerra

Mais do que alcança humano entendimento

A quem no Céu, no mar, na flor, na serra

Sabe o homem mortal com pensamento

Sobre quanto descobre o sol na terra

Tudo o que em cima está do quarto assento

Tudo de vós depende, e deste seio

De vós, que sois do mundo fixo esteio

O ser humano junto e o ser divino

Haver senhor em vós claro se alcança

A quem no rio adoro cristalino

Que o seu curso fazendo não descansa

Essa vista do trono diamantino 
Vosso retrato em mim perfeito alcança

O qual é tão sublime que depende

Desse ser que só ele a si se estende

Ó quanto nesta vida o mortal erra

Quando seguindo vai seu pensamento

Um homem vivo ou já desfeito em terra

Da lei da vida rigorosa isento

Penetra quanto o peito humano encerra

$O$ vosso singular conhecimento

Só desse ser de graça ilustre cheio

Remédio certo espero a meu enleio

Pois por subir-me ao Céu desceis à terra

Comprando meu prazer com sofrimento

Pois á chora do vício em mim se aferra

Tomando as velas eu do entendimento

E pois eu mesmo a mim me faço a guerra

Que acarretando às costas meu tormento

A minha perdição própria granjeio

Vós a tanta soltura ponde o freio

Feito de imenso Deus pobre menino

Pagastes vós, senhor, minha fiança

Assim que se alguma hora isto imagino

Num mar d'águas profundo a dor me lança

Armado contra mim meu peito indino

Contra meu próprio peito em resto a lança

Eu sou o fero imigo que me ofende

Vosso poder em mim meu erro emende

Vosso desejo alcance o seu efeito

Porque só salvar almas desejais

De dor se me congela a voz no peito

Dor que lanço do triste peito em ais

A voz por meu seguro escudo aceito

Vossa ajuda me dai que a todos dais

Em vós tereis, senhor, mui certo abrigo

Tudo terei se vos tiver comigo

Porque eu alcançar possa um ser perfeito

$\mathrm{Na}$ cidade suprema em que habitais

Guia me sede neste passo estreito

Alívio só de miseros mortais

Contra os dardos que vem contra o meu peito

(Se para ajudar todos sempre pronta estais)

Da força de tão fero e falso imigo

Vosso favor me acuda em meu perigo 